Research Paper

\title{
ASSESSMENT OF RELATIONSHIPS BETWEEN CHLOROPHYLL A AND WATER QUALITY IN SOUTH KOREA RESERVOIRS RELAT- ING SUMMER MONSOON
}

\author{
Bach Quang-Dung1, Yongsik Shin ${ }^{2}$
}

\section{ARTICLE HISTORY}

Received: March 08, 2020 Accepted: April 18, 2020

Publish on: April 25, 2020

\section{ABSTRACT}

Variations of chlorophyll a in relation with freshwater quality in Korean reservoirs were investigated during the period of 1992-2006. This study compared assessed total nitrogen (TN), total phosphorus (TP), total suspended solids (TSS), Secchi depth (SD) and phytoplankton biomass (Chlorophyll a (Chl)) relating to pre-monsoon, monsoon and post-monsoon in South Korea reservoirs. Linear relationships were observed between log-transformed Chl and logtransformed TN, TP, TSS, SD and applied for all study sites to examine relationship of these factors in South Korea reservoirs. The results demonstrated that phytoplankton biomass responded to nitrogen and phosphorus enrichment and was also differently and remarkably related to TSS, SD in Korean reservoirs during pre-monsoon, monsoon and post-monsoon.

Keywords: Phytoplankton biomass, freshwater quality, Korean reservoirs, monsoon.

\section{Introduction}

Water quality and trophic status in Sembrong reservoir during monsoon season has investigated by Hashim et al. (2018). The temperature, dissolved oxygen, $\mathrm{pH}$ value, ammonia nitrogen and trophic status parameters such as: chlorophyll, total phosphorus and Secchi depth were considered for 17 locations along Sembrong reservoir identified for sampling activities. The water quality in Sembrong reservoir was not good condition during monsoon season which the chlorophyll contents, total phosphorus and ammonia nitrogen were high.

Kim et al. (2014) has studied relating to seasonal and inter-annual patterns of water chemistry such as: eight physico-chemical parameters such as nitrogen, phosphorus, BOD, COD and chlorophyll a of Miho Stream watershed during 2004 - 2007 along with some influences of tributaries and summer monsoon on the stream water quality. This study analyzed relation of spatial and temporal variability of seven sampling sites of the mainstream and some tributaries in the watershed (Kim et al., 2014).

In South Korea, reservoirs were constructed for irrigation, water supply and flooding control. Freshwater for water supply (mountain reservoirs and Nakdong river system) has been very

$\triangle$ BACH QUANG DUNG

Corresponding author: dungmmu05@gmail.com

${ }^{1}$ Vietnam Journal of Hydrometeorology, Vietnam Meteorological and Hydrological Administration, Hanoi, Vietnam

${ }^{2}$ Department of Environmental Engineering \& Biotechnology, Mokpo National Maritime University, Mokpo 58628, South Korea 
important for social economy (Chun et al., 2001). Bach et al. (2009) developed the study about long-term paradigm analyses of chlorophyll a and water quality in reservoir systems of Korea. The study emphasized the water quality differences between terrestrial freshwater reservoir and coastal freshwater reservoir systems. Water quality of coastal freshwater reservoir system was more significantly decreasing than the reservoirs located in in-land during long-term study (Bach et al., 2009). Eutrophication for Korean reservoirs was studied by Jones et al. (1997); Kim et al. (2001); An and Park (2002).

In the investigation, multi-reservoir study allows to identify the characteristics of nutrient loading which must be controlled to maintain desirable water quality. This study also aims to evaluate the variations of total nitrogen, total phosphorus, total suspended solids, Secchi disk depth and phytoplankton biomass (chlorophyll a) for a comparison among pre-monsoon, monsoon and post-monsoon in South Korea reservoirs.

\section{Methods}

Phytoplankton biomass (chlorophyll a), total nitrogen (TN), total phosphorus (TP), Secchi depth (SD) and total suspended solids (TSS) were analyzed from Koean reservoir systems (including 9 reservoirs: Asan, Sapkyo, Geum, Youngsan, Nakdong, Okchong, Andong, Juam and Deachung) (Fig. 1). Data were chosen from 3 stations for each reservoir. Monthly data including chlorophyll a, TN, TP, SD and TSS were obtained from water quality monitoring program (Korea Ministry of Environment). In South Korea, monsoon is usually from July to August. This study chose pre-monsoon from January to June and post-monsoon selected from September to December. TN was measured by using Kjeldahl nitrogen method and spectrophotometric analyses and TP was measured by standard molybdate-based and spectrophotometric methods (Greenberg et al., 1992). Chlorophyll a (Chl) was measured by fluorescence method. Secchi depth was used to measure water transparency. TSS was determined by using procedure for total suspended solids (Greenberg et al., 1992). Further details of collection and analyses of water quality data were described in http://water.nier.go.kr. Statistical analysis and $\log _{10}$ data were applied for all data to examine the relationships of parameters in Korean reservoir systems.

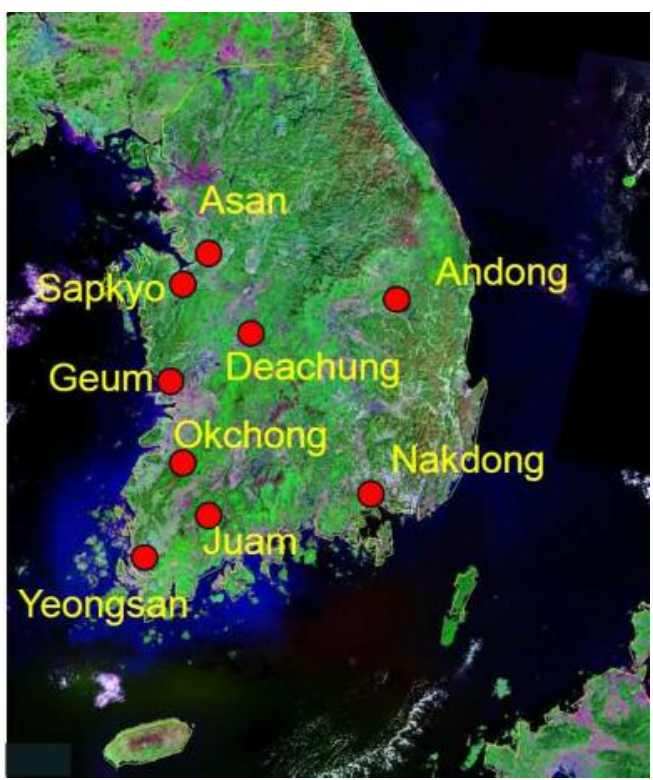

Fig. 1. Koean reservoir systems (including 9 reservoirs: Asan, Sapkyo, Geum, Youngsan,

Nakdong, Okchong, Andong, Juam and Deachung)

\section{Results and discussions}

\subsection{Trend of phytoplankton biomass and} water quality parameters for pre-monsoon, monsoon and post-monsoon in South Korea reservoirs

Mean variations of TN, TP, TSS, SD and Chl for pre-monsoon, monsoon and post-monsoon in South Korea reservoirs shown in Fig. 2. TN concentrations in pre-monsoon were evidently higher than those in monsoon and post-monsoon (Fig. 2a). TN concentration increased from 1992 to 1997 and relatively stabilized from 1998 to 2006 during pre-monsoon $(400-500 \mu \mathrm{M})$. Inversely, TSS values were higher in monsoon 
ranging from 20 to $80 \mathrm{mg} / \mathrm{L}$ (Fig. 3c). The premonsoon period of TP was usually higher than that of the monsoon period, especially in 1995. The post-monsoon period usually had a low TP value except in 1997 and 1998 (Fig. 2b). TSS values were usually high during the monsoon period, reaching exceptionally high values in 2004 and 2005. TSS was quite stable over the years for the pre-monsoon and post-monsoon periods (Fig. 2c). The gradual decreases of Secchi depth were observed for pre-monsoon, monsoon and post-monsoon (Fig. 2d). Chl value reached its highest value in pre-monsoon period (Fig. 2e). $\mathrm{Chl}$ increased during the pre-monsoon period in several years such as 1999 and 2005. Annually, the Chl value of post-monsoon period was usually lower than pre-monsoon or monsoon.

3.2. Relationships between phytoplankton biomass versus nitrogen, phosphorus, total suspended solids and Secchi depth for pre-monsoon, monsoon and post-monsoon in South Korea reservoirs

In this study, linear relationships were observed between log-transformed mean $\mathrm{Chl}$ and log-transformed TN, TP concentrations for all study sites (Figs. 3-4). Relation analysis of logtransformed $\mathrm{Chl}$ against log-transformed $\mathrm{TN}, \mathrm{TP}$ indicated $\mathrm{TN}$ and $\mathrm{TP}$ was positively correlated with phytoplankton biomass (Figs. 3-4). The relations were different for pre-monsoon, monsoon and post-monsoon. TN was more correlated with Chl than TP for all period pre-monsoon, monsoon and post-monsoon. The increase of Chl concentration was clearly affected by the increasing of TN, TP in waterbody in pre-monsoon, monsoon and post-monsoon (Figs. 3-4). Based on correlation analysis, TN enhanced phytoplankton during pre-monsoon and post-monsoon (Figs. 3a,3c) better than during monsoon (Fig. 3b), however, TP had more affective during pre-monsoon period (Fig. 4a).

During pre-monsoon period, it seems that TSS had positively relationship with the increase of Chl (Fig. 5a). However, periods of monsoon and post-monsoon, the relationships were not clear (Fig. 5b,c). This could also be explained that TSS on pre-monsoon was affected and accumulated by microphytoplankton during spring bloom. Fig. 6 shows that negatively correlations between SD and Chl were evident in pre-monsoon and post-monsoon (Figs. 6a,6c). In which, the monsoon period was not clearly shown this relation (Fig. 6b). Thus, SD value is not a decisive factor for the development of phytoplankton. Factors such as nutrition, level of water flux could also be a decisive factor in the growth of phytoplankton.

\subsection{Discussions}

In South Korea, the increases in nutrient concentrations of freshwater due to nutrient inputs from urban and agriculture caused essential increase of nutrient loading into coastal waters, nutrient loadings from non-point sources increased and freshwater discharges into coastal water through embankments were high during summer monsoon.

In the South Korean reservoirs, inter-relations between physical, chemical and biological factors including total nitrogen, total phosphorus, total suspended solids, Secchi disk depth and Chl concentration were analyzed by Bach et al. (2009). Strong curvilinear relationship was fit between log-transformed annual mean $\mathrm{Chl}$ and log-transformed annual mean TP following equation: $\log _{10}(\mathrm{Chl})=0.99+0.88 \log _{10}(\mathrm{TP})$ $0.39 \log _{10}(\mathrm{TP})^{2}$. Transparency of water (SD) related with TSS by inverse third order paradigm: $\mathrm{SD}=0.23+10.85(\mathrm{TSS})^{-1}-13.11(\mathrm{TSS})^{-2}+5.23$ $(\mathrm{TSS})^{-3}$

Cai et al. (2012) analyzed long-term variations of phytoplankton biomass, nutrients, and suspended solids (SS) in Taihu Lake, China, during algal bloom seasons from May to August. Phosphorus and nitrogen loadings from catchments related the risk of phytoplankton blooms. Zou et al. (2020) emphasized that high inorganic suspended solids impacted to relation of nutrient (TN, TP) concentrations and summer Chl in lakes and the relationships between nutrient and $\mathrm{Chl}$ level and SD were used as a theoretical basis 
for lake eutrophication management (Zou et al., 2020).

The relationships between trophic states and their driving factors were investigated such as determination of the spatial and temporal variations in trophic state and identify potential causes for these variations in 60 Korean reservoirs (Mamun et al., 2020), reservoir trophic states varied with environmental and water quality variables (Liu et al., 2017), the differences in algae functional group characteristics in the different water bodies in the region were identified water temperature and nutritional states ( $\mathrm{Lu}$ et al., 2018), relations between variations in the lake bacterioplankton abundance and the lake trophic state (Adamovich et al., 2019).
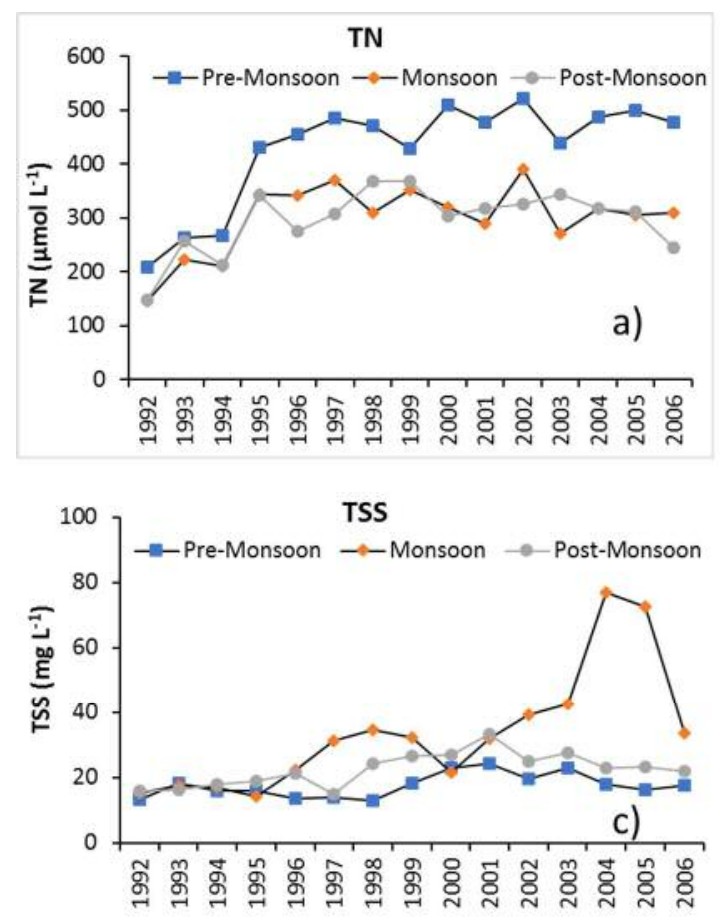

An investigation on the reservoir system in South Korea divided by the pre-monsoon, monsoon, post-monsoon periods helps managers or researchers to better understand the effects of monsoon affecting the ecology of reservoirs. There have been studies on the effects of phytoplankton and variation factors relating to monsoon (Xiao et al., 2011; Bharathi and Sarma, 2019; Li et al., 2020). However, in recent, there were not many researches worked under the premonsoon, monsoon, post-monsoon periods. Therefore, this is a meaningful study that contributes to a better assessment of the trophic state of reservoirs in the context of increasing nutrient loading from point sources and non-point sources.
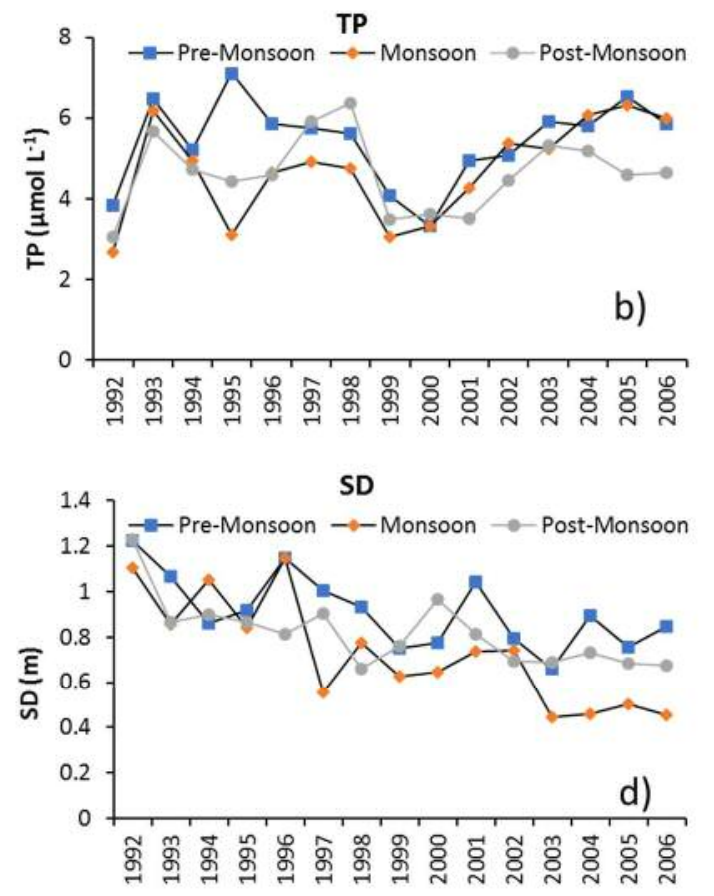

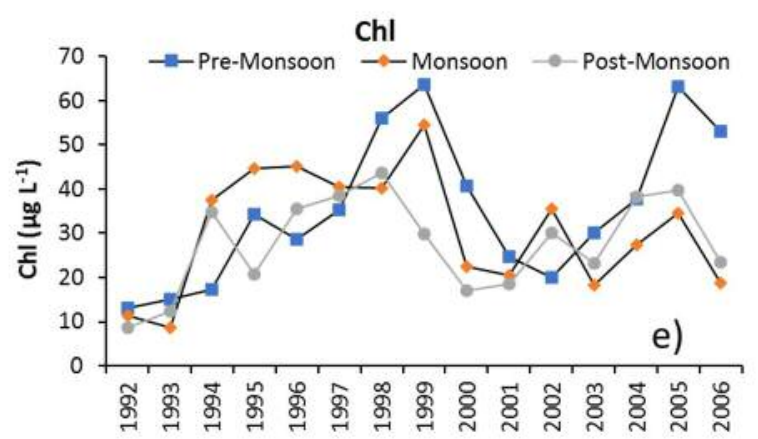

Fig. 2. Variations of Total Nitrogen (TN), Total Phosphorus (TP), Total Suspended Solids (TSS), Secchi disk depth (SD) and Chlorophyll a (Chl) relating to pre-monsoon, monsoon, post-monsoon from all study sites during period 1992-2006 

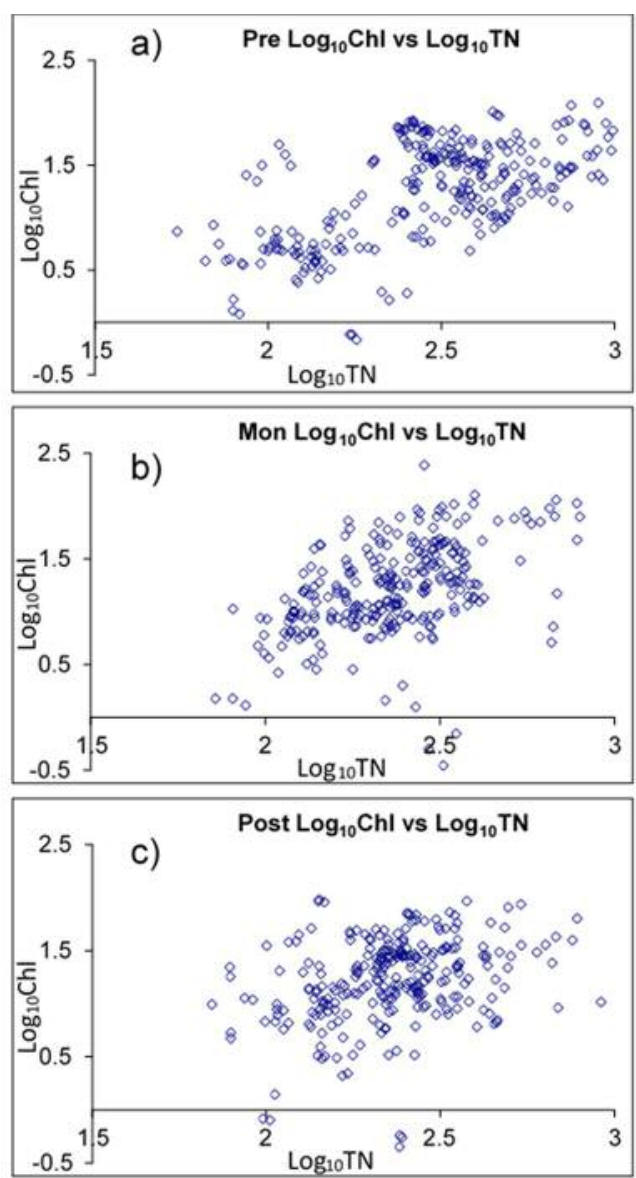

Fig. 3. Relations of log-transformed TN vs. logtransformed Chl relating to pre-monsoon, monsoon, post-monsoon collected from South Korean reservoirs during period 1992-2006
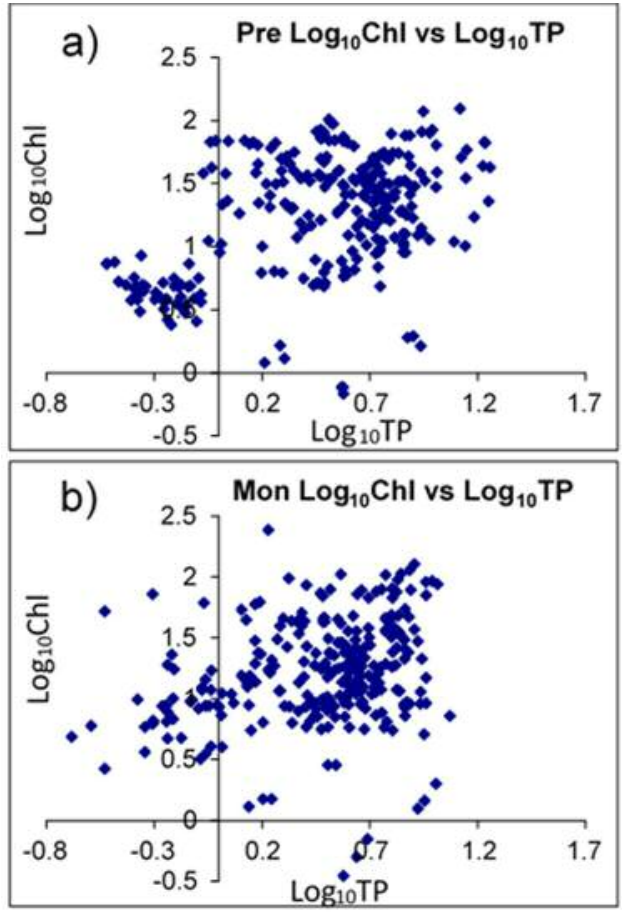

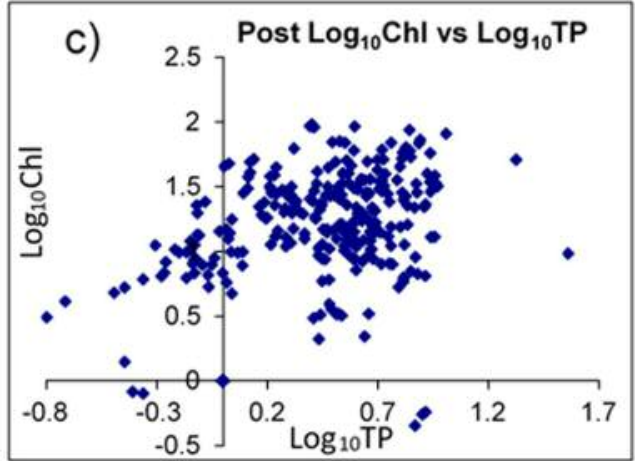

Fig. 4. Relations of log-transformed TP vs. logtransformed Chl relating to pre-monsoon, monsoon, post-monsoon collected from South Korean reservoirs during period 1992-2006
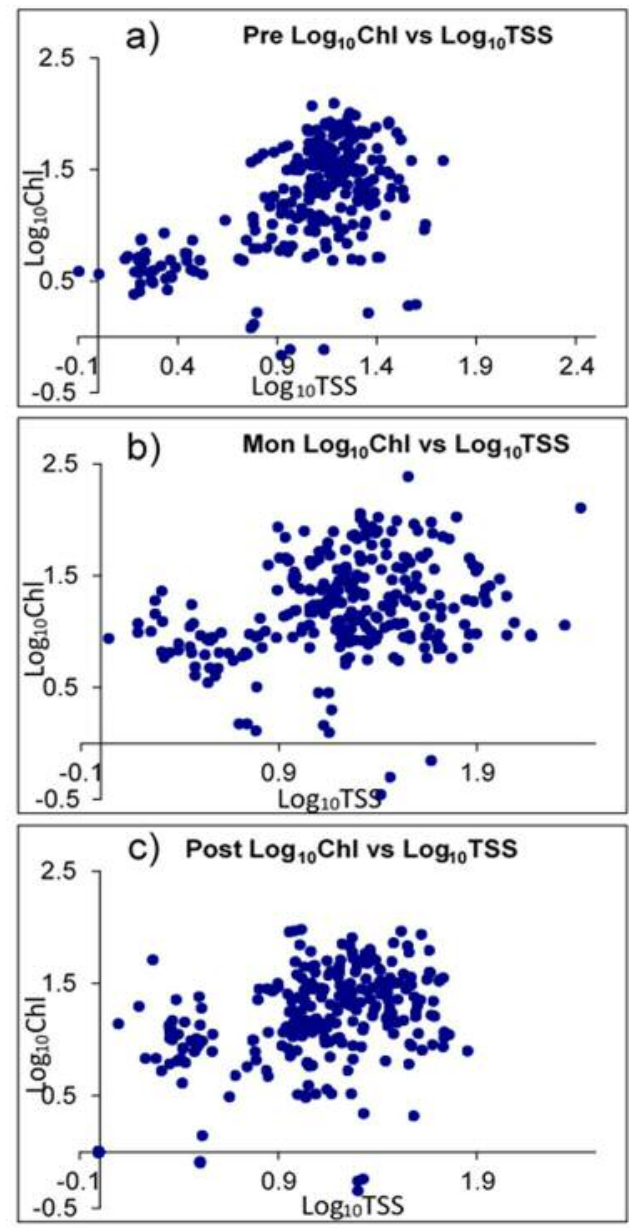

Fig. 5. Relations of log-transformed TSS vs. log-transformed Chl relating to pre-monsoon, monsoon, post-monsoon collected from South Korean reservoirs during period 1992-2006 


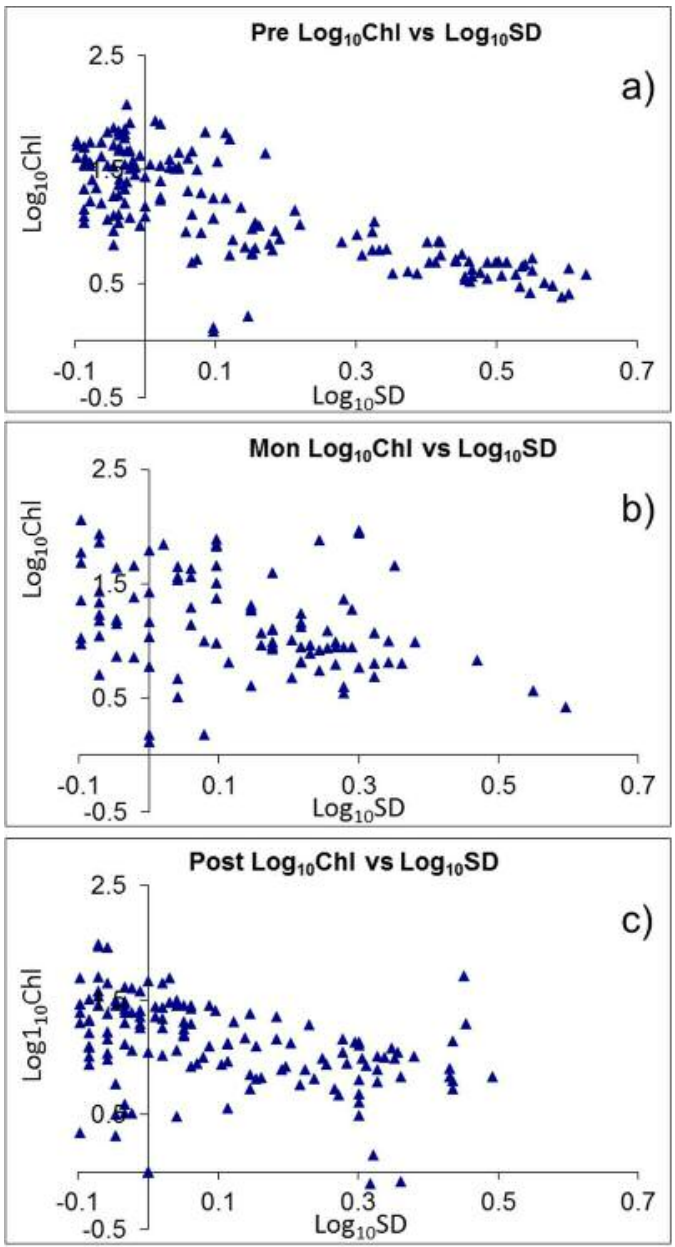

Fig. 6. Relations of log-transformed SD vs. logtransformed Chl relating to pre-monsoon, monsoon, post-monsoon collected from South Korean reservoirs during period 1992-2006

\section{Conclusions}

In conclusion, this study compared assessed total nitrogen, total phosphorus, total suspended solids, Secchi depth and phytoplankton biomass relating to pre-monsoon, monsoon and postmonsoon in South Korea reservoirs. The study contributes to more understanding the Korean reservoirs in which nutrient enrichment can modify primary production $(\mathrm{Chl})$ during monsoon as well as pre-monsoon and post-monsoon. The results may help researchers and managers to refer to phytoplankton biomass responded to nutrient enrichment and environment factors during summer monsoon.

\section{References}

1. Adamovich, B.V., Medvinsky, A.B., Nikitina, L.V., Radchikova, N.P., Mikheyeva, T.M., Kovalevskaya, R.Z., Zhukova, T.V., 2019. Relations between variations in the lake bacterioplankton abundance and the lake trophic state: Evidence from the 20-year monitoring. Ecological Indicators, 97: 120-129.

2. An, K.G., Park, S.S., 2002. Indirect influence of the summer monsoon on chlorophylltotal phosphorus models in reservoirs: a case study. Ecological Modelling, 152: 191-203.

3. Bach, Q.D., Shin, Y.S., Song, E.S., 2009. Long-term paradigm analyses of chlorophyll a and water quality in reservoir systems. Korean Journal Limnology, 42(4): 432-440.

4. Bharathi, M.D., Sarma, V.V.S.S., 2019. Impact of monsoon-induced discharge on phytoplankton community structure in the tropical Indian estuaries. Regional Studies in Marine Science, 31: 100795. Doi.org/10.1016/j.rsma.2019.100795.

5. Cai, L.L., Zhu, G.W., Zhu, M.Y., Xu, H., Qin, B.Q., 2012. Effects of temperature and nutrients on phytoplankton biomass during bloom seasons in Taihu Lake. Water Science and Engineering, 5(4): 361-374.

6. Chun, K.C., Chang, R.W., Williams, G.P., Chang, Y.S., Tomasko, D., LaGory, K., Ditmars, J., Chun, H.D., Lee, B.K., 2001. Water quality issues in the Nakdong river basin in the republic of Korea. Environmental Engineering and Policy, 2: 131-143.

7. Greenberg A.E., Clesceri, L.S., Eaton, A.D., 1992. Standard methods for examination of water \& wastewater Vol. 18. Amarican Public Health Association, Washington D.C.

8. Hashim, S.I.N.S., Talib, S.H.A., Abustan, M.S., Tajuddin, S.A.M., 2018. Water quality and trophic status study in Sembrong reservoir during monsoon season. IOP Conference Series Earth and Environmental Science, 140(1): 012079, DOI: $\quad 10.1088 / 1755$ 1315/140/1/012079.

9. Jones, J.R., Knowlton, M.F., An, K.G., 
1997. Developing a paradigm to study and model the eutrophication process in Korean reservoirs. Korean Journal Limnology, 30: 463-471.

10. Kim, B., Park, J.H., Hwang, G., Jun, M.S., Choi, K., 2001. Eutrophication of reservoirs in South Korea. Limnology, 2(3) : 223229.

11. Kim, J.I., Choi, J.W., An, K.G., 2014. Spatial and temporal variations of water quality in an urban Miho Stream and some influences of the tributaries on the water quality. Journal of Environment Science Internatiotnal, 23(3): 433-445.

12. Mamun, M., Kwon, S., Kim, J.E., An, K.G., 2020. Evaluation of algal chlorophyll and nutrient relations and ratios along with trophic status, light regime in 60 Korea reservoirs. Scince of The Total Environment, 140451. Doi.org/10.1016/j.scitotenv.2020.140451.

13. Li, Y., Nwankwegu, A.S., Huang, Y., Norgbey, E., Paerl, H.W., Achary, K., 2020. Evaluating the phytoplankton, nitrate, and ammonium interactions during summer bloom in tributary of a subtropical reservoir. Journal of Environmental Management, 271, Doi.org/10.1016/j.jenvman.2020.110971.
14. Liu, W., Zhao, E., Kuo, Y.M., Jang, C.S., 2017. Identifying the relationships between trophic states and their driving factors in the Shihmen Reservoir, Taiwan. Limnologica - Ecology and Management of Inland Waters, 64: 38-45.

15. Lu, J., Yang, Z., Zhang, Y., 2018. Algae functional group characteristics in reservoirs and lakes with different trophic levels in northwestern semi-humid and semi-arid regions in China. Journal of Environmental Sciences, 64, 166-173.

16. Xiao, L.J., Wang, T., Hu, R., Han, B.P., Wang, S., Qian, X., Padisák, J., 2011. Succession of phytoplankton functional groups regulated by monsoonal hydrology in a large canyon-shaped reservoir. Water Research, 45(16): 5099-5109.

17. Zou, W., Zhu, G., Cai, Y., Vilmi, A., Xu, H., Zhu, M., Qin, B., 2020. Relationships between nutrient, chlorophyll a and Secchi depth in lakes of the Chinese Eastern Plains ecoregion: Implications for eutrophication management. Journal of Environmental Management, 260: 109923 . doi.org/10.1016/j.jenvman.2019.109923. 